\title{
EFFECT OF MAGNESIUM SULFATE IN ATTENUATING ARTERIAL BLOOD PRESSURE IN ELECTIVE LAPAROSCOPIC ABDOMINAL SURGERIES
}

\author{
Maya $G^{1}$, Ramya $N^{2}$, Anzar $S^{3}$, Shiny Gangadharan ${ }^{4}$ \\ ${ }^{1}$ Additional Professor, Department of Anaesthesiology, GMC, Kollam. \\ ${ }^{2}$ Former Postgraduate Student, Department of Anaesthesiology, GMC, Thiruvananthapuram. \\ ${ }^{3}$ Assistant Professor, Department of Anaesthesiology, GMC, Kollam. \\ ${ }^{4}$ Assistant Professor, Department of Anaesthesiology, GMC, Kollam.
}

ABSTRACT

\section{BACKGROUND}

A Prospective Randomised Control Trial was done to evaluate the effect of Magnesium Sulfate on haemodynamic parameters in patients undergoing elective laparoscopic abdominal surgeries.

\section{MATERIALS AND METHODS}

80 patients were divided into 2 groups of 40 each. Group A received Magnesium Sulfate $50 \mathrm{mg} / \mathrm{kg}$ and Group B received $50 \mathrm{~mL}$ Normal Saline.

Statistical Analysis used- The statistical difference in age, weight, height of the subjects and haemodynamic parameters such as pulse rate, systolic blood pressure, diastolic blood pressure and sedation were compared. Quantitative data is summarised using mean and standard deviation. The difference in mean between quantitative variable was tested using student's ' $t$ ' test.

\section{RESULTS}

The baseline characteristics of the Intervention and Control groups were comparable and there was no significant difference between the groups. Systolic and Diastolic BP were higher in Control group than magnesium group. There was no significant difference in sedation levels in both groups.

\section{CONCLUSION}

In our study, we conclude that IV magnesium sulfate, when given before pneumoperitoneum attenuates arterial pressure increase during elective laparoscopic abdominal surgeries. This attenuation is apparently related to reductions in the release of catecholamine, vasopressin or both by magnesium sulfate. We also found that there is no adverse effect of magnesium like sedation or prolonged neuromuscular blockade at the dose we used.

\section{KEYWORDS}

Magnesium Sulfate, Arterial Pressure, Anaesthesia- General, Laparoscopy, Pneumoperitoneum.

HOW TO CITE THIS ARTICLE: Maya G, Ramya N, Anzar S, et al. Effect of magnesium sulfate in attenuating arterial blood pressure in elective laparoscopic abdominal surgeries. J. Evolution Med. Dent. Sci. 2017;6(33):2680-2683, DOI: 10.14260/Jemds/2017/578

\begin{abstract}
BACKGROUND
Laparoscopic surgery has become the standard procedure for many surgical pathologies. However, the physiological effects of pneumoperitoneum are of concern. ${ }^{1}$ The creation of pneumoperitoneum with carbon dioxide $\left(\mathrm{CO}_{2}\right)$ produces unique haemodynamic challenge for the anaesthetic management of patients. The increased intra-abdominal pressure during pneumoperitoneum together with the headup tilt leads to alterations in cardiovascular, respiratory, stress response and acid base physiology. The changes in cardiovascular system associated with pneumoperitoneum includes an increase in mean arterial pressure, decrease in cardiac output and increase in systemic vascular resistance which can lead to altered tissue perfusion.
\end{abstract}

Financial or Other, Competing Interest: None.

Submission 19-02-2017, Peer Review 11-04-2017,

Acceptance 17-04-2017, Published 24-04-2017.

Corresponding Author:

Dr. Shiny Gangadharan,

Assistant Professor,

Department of Anaesthesiology,

Government Medical College,

Kollam, Kerala.

E-mail: shinyaghosh@gmail.com

DOI: $10.14260 /$ jemds $/ 2017 / 578$
These changes are most likely due to increased release of catecholamines, vasopressin ${ }^{2}$ or both. Severe increases in arterial pressure can be a risk factor in patients with preexisting essential hypertension, ischaemic cardiac disease or increased intracranial/intraocular pressure. Various surgical methods like change in nature of insufflating gas, ${ }^{3}$ use of low intra-abdominal pressure,, 45 use of abdominal wall lift methods ${ }^{6}$ etc. have been tried to decrease the haemodynamic alterations seen with pneumoperitoneum, but all with practical limitations. Various anaesthetic interventions like use of epidural, segmental spinal, 7 combined epidural and general anaesthesia, ${ }^{8}$ use of pharmacological interventions like nitroglycerine, ${ }^{9}$ esmolol, ${ }^{10}$ magnesium sulphate ${ }^{11}$ have also been used with varying success.

Magnesium blocks the release of catecholamines from both adrenergic nerve terminals and the adrenal gland. ${ }^{12}$ Moreover, magnesium produces vasodilatation by acting directly on blood vessels and high dose magnesium is found to attenuate vasopressin stimulated vasoconstriction and normalises sensitivity to vasopressin.

In this study, we have investigated the ability of magnesium sulfate to modulate hypertension and neurohormonal responses in patients undergoing elective laparoscopic abdominal surgeries using $\mathrm{CO} 2$ pneumoperitoneum. 


\section{Aims}

To study the effect of magnesium sulfate on haemodynamic parameters during elective laparoscopic abdominal surgeries.

\section{Primary Objective}

To study the effect of magnesium sulfate on pulse rate, systolic blood pressure and diastolic blood pressure.

\section{Secondary Objective}

To evaluate sedation or any other side effect of the drug.

\section{MATERIALS AND METHODS}

\section{Study Period}

Six months.

\section{Study Design}

Prospective randomised control trial.

\section{Study Approval}

The study was approved by the Institutional Medical Ethics Committee and written informed consent was obtained from all included patients.

\section{Sample Size}

In the haemodynamic changes, the most important outcome measure is systolic blood pressure. Thus, expecting a 15 mmHg difference in systolic blood pressure between the Intervention and Control groups, a 95\% confidence interval, power $85 \%$ and population variance 500 , the sample size calculated for each arm was 40 .

\section{Patient Selection}

All adult male patients aged 18 - 50 years, American Society of Anaesthesiologists Grade I/II with informed written consent and Mallampati score of up to Class II undergoing elective laparoscopic abdominal surgery under general anaesthesia were included. Patients with systemic disorders, on calcium channel blockers and in whom the surgery could not be completed laparoscopically were excluded.

\section{Study Groups \\ Group A}

Magnesium Sulfate group- 40 patients.

\section{Group B}

Control group- 40 patients.

\section{Randomisation}

A computer generated randomisation allotted equal number of patients in each group.

\section{Method of Collection of Data}

A thorough pre-anaesthesia examination of the patient was conducted. The patient was examined the previous day. The procedure was explained and written informed consent was obtained. The patient was kept fasting since the previous night. Oral premedication of tablet Pantoprazole $40 \mathrm{mg}$, tablet Ondansetron $4 \mathrm{mg}$ and tablet Alprazolam $0.25 \mathrm{mg}$ were given at $10 \mathrm{p} . \mathrm{m}$. the day before surgery and at $6 \mathrm{a} . \mathrm{m}$. on the day of surgery.
On the morning of surgery, patient was examined again Once shifted to the Operation theatre, electrocardiogram, pulse oximeter, peripheral nerve stimulator, non-invasive blood pressure monitor and end-tidal $\mathrm{CO} 2\left(\mathrm{etCO}_{2}\right)$ monitor were attached. The patient's vitals were checked and noted at every 5 mins. interval.

The patient was preoxygenated for 3 mins. with 100\% oxygen. Premedicated and induced with injection glycopyrrolate $0.01 \mathrm{mg} / \mathrm{kg}$, injection midazolam $0.03 \mathrm{mg} / \mathrm{kg}$ $\mathrm{mg}$, injection morphine $0.1 \mathrm{mg} / \mathrm{kg}$, injection thiopentone 3 - 5 $\mathrm{mg} / \mathrm{kg}$, intubation facilitated with injection succinylcholine $1.5 \mathrm{mg} / \mathrm{kg}$.

Immediately after intubation, just before pneumoperitoneum, patient received magnesium sulfate 50 $\mathrm{mg} / \mathrm{kg}$ in $50 \mathrm{~mL}$ normal saline (Group A) or normal saline 50 $\mathrm{mL}$ (Group B) infused over 3 - 5 minutes.

Patient was then maintained on 02 in $50 \%$ air, isoflurane $2-3 \%$, injection vecuronium for maintenance of muscle paralysis. $\mathrm{CO}_{2}$ pneumoperitoneum was created and intraabdominal pressure was maintained between 12 - 14 $\mathrm{mmHg}, \mathrm{EtCO}_{2}$ between 35 - $45 \mathrm{mmHg}$. Isoflurane was turned off when last port was sutured.

Residual neuromuscular blockade was reversed using injection neostigmine $0.05 \mathrm{mg} / \mathrm{kg}$ with injection glycopyrrolate $0.02 \mathrm{mg} / \mathrm{kg}$ when TOF count is 4 . Extubation was performed using Double Burst Stimulation (DBS).

\section{Assessment}

Pulse Rate (PR), Systolic Blood Pressure (SBP), Diastolic Blood Pressure (DBP) readings were recorded before induction, post induction before pneumoperitoneum, every five minutes after pneumoperitoneum till thirty minutes, then every fifteen minutes till end of surgery.

Sedation evaluated using Ramsay sedation scale.

\section{Statistical Analysis used}

Data was analysed using computer software "Statistical Package for Social Sciences" (SPSS). Quantitative data is summarised using mean and standard deviation. The difference in mean between quantitative variable tested using student's ' $t$ ' test.

\section{RESULTS}

Two groups of 40 each were labelled as Group A (magnesium sulfate $50 \mathrm{mg} / \mathrm{kg}$ )- Intervention group and Group B (Normal Saline $50 \mathrm{~mL}$ )- Control group. The mean of patients' age, weight and height were calculated between the two groups and were tabulated as shown below. Thus, it was concluded on the basis of the $\mathrm{p}$ value that the distribution of age, weight and height among the two groups were comparable and these factors did not have any influence on outcome.

\begin{tabular}{|c|c|c|c|}
\hline Parameter & $\begin{array}{c}\text { Group A } \\
\text { Mean (SD) }\end{array}$ & $\begin{array}{c}\text { Group B } \\
\text { Mean (SD) }\end{array}$ & P value \\
\hline Age (years) & $32.85(9.62)$ & $30.15(8.21)$ & 0.1807 \\
\hline Height (cm) & $158.58(6.94)$ & $160.45(6.69)$ & 0.2224 \\
\hline Weight (kg) & $65.10(10.21)$ & $62.45(6.61)$ & 0.1721 \\
\hline \multicolumn{4}{|c|}{ Table 1. Demographic Profile } \\
\hline
\end{tabular}


Comparison of Observations

\begin{tabular}{|c|c|c|c|c|c|}
\hline & $\begin{array}{c}\text { Group A } \\
\text { Mean } \\
\text { (SD) }\end{array}$ & $\begin{array}{c}\text { Group B } \\
\text { Mean } \\
\text { (SD) }\end{array}$ & T-value & df & P-value \\
\hline $\begin{array}{c}\text { Pre-induction } \\
\text { HR }\end{array}$ & $\begin{array}{c}74.93 \\
(7.47)\end{array}$ & $\begin{array}{c}74.38 \\
(7.79)\end{array}$ & 0.3222 & 78 & .7482 \\
\hline $\begin{array}{c}\text { Post-induction } \\
\text { HR }\end{array}$ & $\begin{array}{c}76.40 \\
(7.41)\end{array}$ & $\begin{array}{c}74.38 \\
(7.79)\end{array}$ & 1.2120 & 78 & .2292 \\
\hline HR 5 mins & $\begin{array}{c}75 \\
(7.004)\end{array}$ & $\begin{array}{c}77.15 \\
(5.824)\end{array}$ & 1.2574 & 78 & .2124 \\
\hline HR 10 mins & $\begin{array}{c}74.63 \\
(6.29)\end{array}$ & $\begin{array}{c}74.15 \\
(6.32)\end{array}$ & 0.3368 & 78 & .7372 \\
\hline HR 20 mins & $\begin{array}{c}75.40 \\
(6.15)\end{array}$ & $\begin{array}{c}74.28 \\
(6.22)\end{array}$ & 0.8138 & 78 & .4183 \\
\hline HR 30 mins & $\begin{array}{c}72.25 \\
(6.36)\end{array}$ & $\begin{array}{c}73.78 \\
(7.50)\end{array}$ & 0.9814 & 78 & .3294 \\
\hline
\end{tabular}

Table 2. Comparison of Heart Rate (HR) at different Point of Time between Group A and Group B

The heart rate between Intervention group and Control group were compared pre- and post-induction at 5 mins, 10 mins, 20 mins, 30 mins. There was no difference in Group A (Intervention group) and Group B (Control group).

\begin{tabular}{|c|c|c|c|c|c|}
\hline & $\begin{array}{c}\text { Group A } \\
\text { Mean } \\
\text { (SD) }\end{array}$ & $\begin{array}{c}\text { Group B } \\
\text { Mean } \\
\text { (SD) }\end{array}$ & T-value & df & P-value \\
\hline $\begin{array}{c}\text { Pre-induction } \\
\text { SBP }\end{array}$ & $\begin{array}{c}122.58 \\
(11.64)\end{array}$ & $\begin{array}{c}122.05 \\
(11.03)\end{array}$ & 0.2071 & 78 & .8365 \\
\hline $\begin{array}{c}\text { Post-induction } \\
\text { SBP }\end{array}$ & $\begin{array}{c}123.10 \\
(12.02)\end{array}$ & $\begin{array}{c}121.95 \\
(13.05)\end{array}$ & 0.7666 & 78 & .4457 \\
\hline $\begin{array}{c}\text { Systolic BP at } \\
5 \text { minutes }\end{array}$ & $\begin{array}{c}118.0 \\
(9.52)\end{array}$ & $\begin{array}{c}135.7 \\
(12.97)\end{array}$ & 6.9561 & 78 & $<0.001$ \\
\hline $\begin{array}{c}\text { Systolic BP at } \\
10 \text { minutes }\end{array}$ & $\begin{array}{c}113.7 \\
(9.33)\end{array}$ & $\begin{array}{c}139.8 \\
(11.81)\end{array}$ & 10.9674 & 78 & $<0.001$ \\
\hline $\begin{array}{c}\text { Systolic BP at } \\
20 \text { minutes }\end{array}$ & $\begin{array}{c}113.4 \\
(8.92)\end{array}$ & $\begin{array}{c}139.50 \\
(11.25)\end{array}$ & 11.4970 & 78 & $<0.001$ \\
\hline $\begin{array}{c}\text { Systolic BP at } \\
30 \text { minutes }\end{array}$ & $\begin{array}{c}113.3 \\
(8.43)\end{array}$ & $\begin{array}{c}137.9 \\
(12.24)\end{array}$ & 10.4651 & 78 & $<0.001$ \\
\hline $\begin{array}{c}\text { Table 3. Comparison of Systolic Blood Pressure (SBP) at } \\
\text { different Point of Time between Group A and Group B }\end{array}$ \\
\hline
\end{tabular}

The systolic BP between Group A (Intervention group) and Group B (Control group) were compared at 5 mins, 10 mins, 20 mins and 30 mins. There was reduction in systolic BP post-intubation in Intervention group, which was found to be statistically significant $(\mathrm{P}<0.001)$.

\begin{tabular}{|c|c|c|l|l|l|}
\hline & $\begin{array}{c}\text { Group A } \\
\text { Mean } \\
\text { (SD) }\end{array}$ & $\begin{array}{c}\text { Group B } \\
\text { Mean } \\
(\text { SD) }\end{array}$ & T -value & Df & P value \\
\hline $\begin{array}{c}\text { Pre- } \\
\text { induction DBP }\end{array}$ & $\begin{array}{c}75.35 \\
(6.39)\end{array}$ & $\begin{array}{c}75.25 \\
(6.88)\end{array}$ & 0.0650 & 78 & 0.9484 \\
\hline $\begin{array}{c}\text { Post-induction } \\
\text { DBP }\end{array}$ & $\begin{array}{c}74.43 \\
(5.96)\end{array}$ & $\begin{array}{c}74.30 \\
(7.98)\end{array}$ & 0.0794 & 78 & 0.9369 \\
\hline DBP 5 mins & $\begin{array}{c}70.30 \\
(4.16)\end{array}$ & $\begin{array}{c}83.60 \\
(11.45)\end{array}$ & 6.9036 & 78 & $<0.001$ \\
\hline DBP 10 mins & $\begin{array}{c}67.70 \\
(4.01)\end{array}$ & $\begin{array}{c}86.20 \\
(11.26)\end{array}$ & 9.7898 & 78 & $<0.001$ \\
\hline DBP 20 mins & $\begin{array}{c}68.25 \\
(3.18)\end{array}$ & $\begin{array}{c}84.95 \\
(10.67)\end{array}$ & 9.4875 & 78 & $<0.001$ \\
\hline DBP 30 mins & $\begin{array}{c}68.75 \\
(3.81)\end{array}$ & $\begin{array}{c}83.70 \\
(10.44)\end{array}$ & 8.5070 & 78 & $<0.001$ \\
\hline $\begin{array}{c}\text { Table 4. Comparison of Diastolic Blood Pressure (DBP) at } \\
\text { different Point of Time between Group A and Group B }\end{array}$ \\
\hline
\end{tabular}

The diastolic BP between Group A (Intervention group) and Group B (Control group) were compared at 5 mins, 10 mins, 20 mins and 30 mins. There was reduction in DBP in Intervention group, which was statistically significant $(\mathrm{P}<0.001)$.

\begin{tabular}{|c|c|c|c|}
\hline \multirow{2}{*}{ Group } & \multicolumn{2}{|c|}{ Sedation Scale Score } & \multirow{2}{*}{ Total } \\
\cline { 2 - 3 } & $\mathbf{2}$ or Less & Above 2 & \\
\hline $\begin{array}{c}\text { Intervention } \\
\text { group }\end{array}$ & $24(60.0 \%)$ & $16(40.0 \%)$ & $40(100.0 \%)$ \\
\hline $\begin{array}{c}\text { Control } \\
\text { group }\end{array}$ & $24(60.0 \%)$ & $16(40.0 \%)$ & $40(100.0 \%)$ \\
\hline Total & $\mathbf{4 8}(\mathbf{6 0 . 0} \%)$ & $\mathbf{3 2}(\mathbf{4 0 . 0} \%)$ & $\mathbf{8 0}(\mathbf{1 0 0 . 0 \% )}$ \\
\hline \multicolumn{4}{|c|}{ Table 5. Comparison of Sedation Score between } \\
Group A and Group B \\
\hline
\end{tabular}

Chi-square $=0.00$, Degree of Freedom $=1, \mathrm{P}$ value $=1.00$. There was no significant difference in the sedation in both groups.

\section{DISCUSSION}

Laparoscopic surgeries are the most common surgeries performed in the present era. Alteration of haemodynamic status in laparoscopic surgeries are unavoidable. Pneumoperitoneum during laparoscopy produces significant haemodynamic changes which can be detrimental, especially in elderly and haemodynamically compromised patients.

In our study, we evaluate whether magnesium sulfate administration before pneumoperitoneum attenuates increases in arterial pressure during $\mathrm{CO}_{2}$ pneumoperitoneum in patients under general anaesthesia.

In our study, the systolic BP measurements were compared between Intervention groups and Control groups at pre-induction, post-induction at $5 \mathrm{mins}, 10 \mathrm{mins}, 20 \mathrm{mins}$ and 30 mins post-induction. It was found that the mean systolic BP in Intervention group was lower compared to Control group after intubation, which was statistically significant.

In a study by Jee et al, ${ }^{11}$ magnesium sulfate $50 \mathrm{mg} / \mathrm{kg}$ was administered over 2 - 3 mins before pneumoperitoneum in patients undergoing laparoscopic cholecystectomy was found to effectively attenuate the effects of pneumoperitoneum by decreasing the systolic BP. In that study, they compared the arterial pressure and heart rate at different time periods and found to have significant increase in systolic BP and diastolic BP in Control group compared to Intervention group.

In our study, the diastolic BP was also compared between Intervention and Control groups at 5 mins, 10 mins, 20 mins and 30 mins and it was found that the diastolic BP in Intervention group was lower compared to Control group which was statistically significant.

In a study by Kalra et al, 13 they compared clonidine and magnesium sulfate in attenuating haemodynamic response to pneumoperitoneum. They found that both clonidine and magnesium were effective in reducing systolic BP and diastolic BP in Intervention group compared to Control group which was statistically significant. Hence, both the drugs were effective in decreasing stress response by reducing systolic and diastolic BP.

In one study, Jean $\mathrm{LJ}$ et $\mathrm{al}^{14}$ concluded that the raise in systemic vascular resistance was due to vasopressin and catecholamines, which were produced after 
pneumoperitoneum. They used clonidine before pneumoperitoneum and found that it reduced catecholamine release and attenuated haemodynamic changes during laparoscopy.

Another study by Ishizaki et al ${ }^{5}$ tried to evaluate the safe intra-abdominal pressure during laparoscopic surgery. They observed significant fall in cardiac output at $16 \mathrm{mmHg}$ of intra-abdominal pressure. Haemodynamic alterations were not observed at $12 \mathrm{mmHg}$ of intra-abdominal pressure. Based on all these observations, the current recommendation is to monitor intra-abdominal pressure and to keep it as low as possible within $10-12 \mathrm{mmHg}$.

In one study, Doyle ${ }^{15}$ gave antenatal magnesium sulfate therapy to women at risk of preterm birth. He established the effect of magnesium sulfate as a neuroprotective agent when given antenatally to women at risk of preterm birth.

Yosry $^{16}$ in one study compared magnesium sulfate and sodium nitroprusside to induce controlled hypotension and to reduce choroidal blood flow during choroidal melanoma resection. Magnesium sulfate reduces intra-operative arterial pressure and provided good surgical conditions.

\section{CONCLUSION}

In our study, we investigated whether magnesium sulfate attenuates haemodynamic stress response to pneumoperitoneum during laparoscopic abdominal surgeries.

The systolic and diastolic blood pressure increased abruptly after creation of pneumoperitoneum. The increase in arterial pressure was sustained during pneumoperitoneum in Control groups. But in magnesium group, haemodynamic response to pneumoperitoneum was effectively blunted.

In our study, we conclude that IV magnesium sulfate when given before pneumoperitoneum attenuates arterial pressure increases during elective laparoscopic abdominal surgeries. This attenuation is apparently related to reductions in the release of catecholamine, vasopressin or both by magnesium sulfate.

Moreover, it is found that vasodilatory effects of magnesium sulfate could provide haemodynamic stability during pneumoperitoneum. Magnesium sulfate can be recommended to avoid pressor response during the induction and maintenance.

In our study, we also found that there is no adverse effect of magnesium like sedation or prolonged neuromuscular blocked at the dose we used.

The mean of patients' age, weight and height were calculated between the two groups. Thus, it was concluded that the distribution of age, weight and height among the two groups were comparable and these factors did not have any influence on outcome.

\section{REFERENCES}

[1] Cunningham AJ, Brull SJ. Laparoscopic cholecystectomy anaesthetic implications. Anesthesia and Analgesia 1993;76(5):1120-33.

[2] Zukerman R, Gold M, Jenkins P, et al. The effects of pneumoperitoneum and patient position on hemodynamics during laparoscopic cholecystectomy. Surgical Endoscopy 2001;15(6):562-5.
[3] Menes T, Spivak H. Laparoscopy searching for the proper insufflation gas. Surgical Endoscopy 2000;14(11):1050-6.

[4] Dexter SP, Vucevic M, Gibson J, et al. Hemodynamic consequences of high- and low-pressure capnoperitoneum during laparoscopic cholecystectomy. Surgical Endoscopy 1999;13(4):37681.

[5] Ishizaki Y, Bandai Y, Shimomura K, et al. Safe intraabdominal pressure of carbon dioxide pneumoperitoneum during laparoscopic surgery. Surgery 1993;114(3):549-54.

[6] Gurusamy KS, Samraj K, Davidson BR. Abdominal lift for laparoscopic cholecystectomy. Cochrane Database Syst Rev 2008;(2):CD006574.

[7] Zundert VAA, Stultiens G, Jakimowicz JJ, et al. Laparoscopic cholecystectomy under segmental thoracic spinal anesthesia: a feasibility study. Br J Anaesth 2007;98(5):682-6.

[8] Youssef MA, saleh Al-Mulhim A. Effects of different anesthetic techniques on antidiuretic harmone secretion during laparoscopic cholecystectomy. Surg Endosc 2007;21(9):1543-8.

[9] Feig BW, Berger DH, Doughtery TB, et al. Pharmacological interventions can reestablish baseline hemodynamic parameters during laparoscopy. Surgery 1994;116(4):733-7.

[10] Koivusalo AM, Scheinin M, Tikkanen I, et al. Effects of esmolol on hemodynamic responses to $\mathrm{CO} 2$ pneumoperitoneum for laparoscopic surgery. Acta Anaesthesiol Scand 1998;42(5):510-7.

[11] Jee D, Lee D, Yun S, et al. Magnesium sulfate attenuates arterial pressure increase during laparoscopic cholecystectomy. Br J Anaesth 2009;103(4):484-9.

[12] Michael FM, James. Calcium and magnesium. In: Thomas EJ, Healy, Paul R, et al, eds. Wylie and Churchill-Davidson's a practice of anaesthesia. $7^{\text {th }}$ edn. London: Arnold 2003:p.342.

[13] Kalra NK, Verma A, Agarwal A, et al. Comparative study of intravenously administered clonidine and magnesium sulfate on hemodynamic responses during laparoscopic cholecystectomy. J Anaesthesiol Clin Pharmacol 2011;27(3):344-8.

[14] Joris JL, Chiche JD, Canivet JL, et al. Hemodynamic changes induced by laparoscopy and their endocrine correlates: effects of clonidine. JACC 1998;32(5):138996.

[15] Doyle LW, Crowther CA, Middleton P, et al. Magnesium sulfate for women at risk of preterm birth for neuroprotection of the fetus. Cochrane Database Syst Rev 2009;(1):CD004661.

[16] Yosry M, Othman IS. Controlled hypotension in adults undergoing choroidal melanoma resection: comparison between the efficacy of nitroprusside and magnesium sulfate. Eur J Anaesthesiol 2008;25(11):891-6. 